\title{
Physicochemical, microbiological characterization and phytotoxicity of digestates produced on single-stage and two-stage anaerobic digestion of food waste
}

\author{
Brayan Alexis Parra-Orobio ${ }^{1 *}$ (D, María Paula Rotavisky-Sinisterra', Andrea Pérez-Vidal², \\ Luis Fernando Marmolejo-Rebellón ${ }^{1}$ and Patricia Torres-Lozada ${ }^{1}$
}

\begin{abstract}
Organic amendments favor the development of sustainable agriculture by using less chemical fertilizers. In this way, the use of digestates from anaerobic digestion as soil conditioners in agriculture has been gaining interest due to their important $\mathrm{N}$ and $\mathrm{P}$ nutrient contents, among others. This study evaluated the potential use of digestates from anaerobic reactors treating food waste in single (D1) and two-stages (D2: hydrolytic/acidogenic and D3:

acetogenic/methanogenic) configurations. Digestate characteristics and their potential application conditions (100, 50, 25, and 5\%) were evaluated using Raphanus sativus as an indicator species. D3 reported the best performance in terms of: (i) better physicochemical, microbiological, and parasitological characteristics, being a class B material, without exceeding the established limits for heavy metals, fecal coliforms ( $F C<1000$ CFU $100 \mathrm{~mL}^{-1}$ ), Salmonella spp. $\left(0 \mathrm{CFU} \mathrm{g}{ }^{-1}\right)$, and viable helminth eggs $\left(0 \mathrm{HE} \mathrm{g}^{-1}\right)$; (ii) better stability indicators on D3, followed by D1 (volatile solids/total solids (VS/TS): 0.57 and 0.65, pH: 8.63 and 6.80, respectively), while D2 was the most unstable digestate (VS/TS > 0.87 and acidic pH); and (iii) greater potential for agricultural use, since a $5 \%$ dose produced a germination index $>120 \%$, whose effect is associated with the presence of humic and fulvic acids and with $\mathrm{N}$ and $\mathrm{P}$ concentrations $>1 \%$. In addition, the study reported that volatile fatty acids $>2500 \mathrm{mg} \mathrm{L}^{-1}$ act as antimicrobial agents, reducing the required pathogen removal pretreatments.
\end{abstract}

Keywords: Digestate, Food waste, Germination, Organic fertilizers, Single and two-stage anaerobic digestion, Sustainable agriculture

\section{Introduction}

Population growth and economic development have increased the demand for food for human consumption, leading to a considerable expansion of the agricultural frontier. This is one of the anthropogenic activities that has exerted the greatest impact on terrestrial ecosystems, since it generates environmental issues such as ground

\footnotetext{
* Correspondence: brayan.parra@correounivalle.edu.co

${ }^{1}$ Faculty of Engineering, Universidad del Valle, Cali 760032, Colombia

Full list of author information is available at the end of the article
}

and surface water pollution, air pollution, and soil degradation. All these problems derive from monocultures, irrigation, and the use of pesticides and fertilizers [1].

One of the strategies implemented by governments and the agro-industrial sector to secure high agricultural production levels has been to foster the use of fertilizers to the point that $50 \%$ of the world population now depends upon them for food production [2]. As a consequence of fertilizer saturation, soil absorption capacities have been reduced and currently only $30-50 \%$ of

(c) The Author(s). 2021 Open Access This article is licensed under a Creative Commons Attribution 4.0 International License, which permits use, sharing, adaptation, distribution and reproduction in any medium or format, as long as you give

appropriate credit to the original author(s) and the source, provide a link to the Creative Commons licence, and indicate if changes were made. The images or other third party material in this article are included in the article's Creative Commons licence, unless indicated otherwise in a credit line to the material. If material is not included in the article's Creative Commons licence and your intended use is not permitted by statutory regulation or exceeds the permitted use, you will need to obtain permission directly from the copyright holder. To view a copy of this licence, visit http://creativecommons.org/licenses/by/4.0/. 
fertilizers are retained in soils, which means that most are released into the environment and therefore more fertilizers will be required in the future [1].

In contrast, the application of organic amendments and the consequential reduction in mineral fertilizers are environmentally-sound and economically-feasible approaches that may foster the development of more sustainable agriculture, and contribute to a circular economy through the exploitation of these byproducts [3].

Anaerobic digestion (AD) has gained an important role as a technological option for the treatment of municipal solid waste (MSW), organic waste and food waste (FW), with most experience focusing on the single-stage configuration. However, two-stage configurations are becoming increasingly popular, since they are more efficient in the management of solid substrates, such as FW, due to increased biogas production, among other aspects.

The main interest in this technological option is due to the production of biogas with a high methane content, a renewable and sustainable energy source [4]. However the digestate continues to be a key challenge, since improper handling can generate negative effects, such as land occupation, nitrogen overloads, transportation costs, the presence of toxic microorganisms, and greenhouse gas emissions [5].

From an agronomic point of view, AD transforms organic waste producing biogas and digestate, which is a mineral reservoir [4]. Therefore, AD leads to the production of significant amounts of ions and metals that are essential and beneficial for plant development [6].

Some studies have shown that the application of anaerobic digestate in soils can have positive effects on their physical properties, such as reducing the apparent density, increasing the saturated hydraulic conductivity and improving the moisture retention capacity, establishing the optimal dose according to the crop and type of waste used to produce the digestate [7].

Additionally, the digestate also has great potential for agricultural application due to the high level of nitrogen $(\mathrm{N})$, phosphorus $(\mathrm{P})$, and potassium $(\mathrm{K})$. Furthermore, quality and crop applicability have been evaluated not only from the point of view of nutrients, but also for the content of heavy metals and pathogens. However, the majority of digestate reports come from single-stage configurations $[5,7,8]$.

In contrast, the study and application of digestates obtained from two-stage configurations have been studied less [6,9] according to authors such as Prochazka [10] and Samaniego and Pedroza-Sandoval [11]. These digestates generate by-products, such as volatile fatty acids (VFAs), which exhibit phytostimulatory or phytopathogenic properties that can benefit crops.
From a normative perspective for the production and use of these by-products, different countries have implemented regulations, finding different aspects related to environmental impacts, health risks and digestate management practices. Some of the European countries that have these types of regulations are Italy [12], Ireland [13], Spain [14], and the UK [15]. In the case of Latin American regulations [16], in general these are derived from the EPA 503B-1994 from the United States on the use of biosolids from municipal sewage treatment plants [17], which are similar to the digestates from $\mathrm{AD}$ of solid waste.

Additionally, in Colombia and throughout Latin America, most of the regulatory framework focuses on organic fertilizers or amendments obtained from composting and manure [18-20]. In Colombia, Decree 1287 of 2014 has been approved, "which establishes criteria for using biosolids generated in anaerobic digesters at municipal sewage treatment plants" [21], and which is also a useful reference for assessing digestates from the $\mathrm{AD}$ of organic substrates such as FW and the biowaste found in MSW.

However, a safe and functional application of this material in agriculture requires in-depth knowledge of its composition, so that possible impacts on the soil and plants may be determined based on its stability and maturity, among other variables [22].

According to the above, the novel aspect of this study focused on evaluating the influence of the configuration of single and two-stage configurations of anaerobic reactors treating FW, from the perspective of the physicochemical, microbiological, parasitological, stability and maturity properties, in addition to evaluating the potential agricultural application of the digestates produced in each configuration, using radish seeds (Raphanus sati$v u s)$ as an indicator species. Furthermore, the regulatory framework of different countries was analyzed, taking into account that in Colombia and some Latin American countries, there are no application standards for organic amendments obtained through anaerobic processes.

\section{Materials and methods}

\section{Digestate sources}

The digestates assessed were taken from the mesophilic semi-continuous anaerobic reactors $\left(35 \pm 1{ }^{\circ} \mathrm{C}\right)$ treating FW from the university restaurant at the Universidad del Valle (Cali, Colombia), which serves 3000 students on a daily basis and generates $86.6 \mathrm{~kg} \mathrm{~d}^{-1}$ of FW. Reactors operate at the following organic loading rates (OLR): (i) single-stage (D1-R1: $9.2 \mathrm{~L}-6.0 \mathrm{~kg}$ volatile solids (VS) $\mathrm{m}^{-3} \mathrm{~d}^{-1}$ ); and (ii) two-stage (D2-R2-Acidogenic Reactor: $5.75 \mathrm{~L}-15.0 \mathrm{~kg}$ VS m${ }^{-3} \mathrm{~d}^{-1}$ and D3-R3-

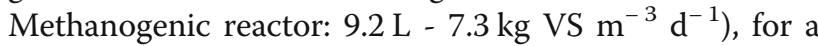
span of $50 \mathrm{~d}$. The solids retention times (SRT) for the 
single-stage configuration (R1) was $7.5 \mathrm{~d}$ while the two-stage configuration (R2 and R3) corresponded to 3.0 and $5.5 \mathrm{~d}$, respectively. This FW simulates the MSW conditions of separation at the source with selective collection, in which FW represents $65 \%$ of the total waste [23].

\section{Physicochemical, microbiological, and parasitological characterization of digestates}

The digestate collection process consisted of liquid and solid fractionation of the material digested in the anaerobic process, which consisted of homogeneously mixing both fractions mechanically. The digestates were stored at a temperature of $4{ }^{\circ} \mathrm{C}$ until their physicochemical, microbiological, and parasitological characterization was conducted, in accordance with the agricultural application standards from the Colombian regulations on organic products used as fertilizers and soil amendments, Colombian Technical Norm (NTC) 5167 [18] and Decree 1287 of 2014 [21], in addition to elements from the US EPA Part 503 rule of 1994 [17], the Italian Decree No. 29 regarding the Use of Digestates on Agriculture [12], and the Irish regulations governing the Agricultural Application of Digestates [13].

The parameters measured herein followed the protocols established by ICONTEC [18] and APHA [24]: pH (potentiometric in a $50 \mathrm{~mL}$ extract of distilled water and a $10 \mathrm{~g}$ sample), moisture (drying process at $100^{\circ} \mathrm{C}$ ), total solids (TS), VS (drying and calcination at 150 and $550^{\circ} \mathrm{C}$, respectively), chemical oxygen demand $\left(\mathrm{COD}_{\text {total }}\right.$ and $\mathrm{COD}_{\text {soluble }}$ ) (closed reflux and spectrophotometryDR 500 spectrophotometer), total organic carbon (TOC) (spectrophotometry-DR 500 spectrophotometer $(\lambda=578$ $\mathrm{nm}$ ), cation exchange capacity (CEC) (using an $50 \mathrm{~mL}$ extract of distilled water and a $10 \mathrm{~g}$ sample), total nitrogen (TN) (Kjeldahl method for total nitrogen titration), total phosphorus (TP) (spectrophotometry- DR 500 spectrophotometer $(\lambda=880 \mathrm{~nm})$, and metals (Copper$\mathrm{Cu}$, Cadmium-Cd, Chromium-Cr, Zinc-Zn, Mercury-Hg, Molybdenum-Mo, Nickel-Ni, Lead-Pb and Selenium-Se) by atomic absorption spectroscopy $(\lambda=324.8 \mathrm{~nm}$ for $\mathrm{Cu}$, $\lambda=228.8 \mathrm{~nm}$ for $\mathrm{Cd}, \lambda=357.9 \mathrm{~nm}$ for $\mathrm{Cr}, \lambda=213.9 \mathrm{~nm}$ for $\mathrm{Zn}, \lambda=254 \mathrm{~nm}$ for $\mathrm{Hg}, \lambda=313.3 \mathrm{~nm}$ for $\mathrm{Mo}, \lambda=232$ $\mathrm{nm}$ for $\mathrm{Ni}, \lambda=216.9 \mathrm{~nm}$ for $\mathrm{Pb}$ and $\lambda=204 \mathrm{~nm}$ for Se).

VFAs (acetic acid-AA, and propionic acid-PrA) and long chain fatty acids (LCFAs: palmitic acid-PA, and oleic acid-OA) were quantified by liquid chromatography $(\lambda=210 \mathrm{~nm})$ using an Agilent Technology gas chromatograph Model 7890B with flame ionization detection and equipped with an HP-FFAP capillary column (30 $\mathrm{mm}$ and an inner diameter of $0.53 \mathrm{~mm}$ ) [23]. The samples were filtered with $0.45 \mu \mathrm{m}$ cellulose acetate, then acidified with concentrated $\mathrm{H}_{3} \mathrm{PO}_{4}(\mathrm{pH}<3.0)$; the injection volume was $0.6 \mu \mathrm{L}$, and the injector and detector temperatures were 250 and $300{ }^{\circ} \mathrm{C}$, respectively.

The microbiological and parasitological parameters characterized were fecal coliforms (FC) (NMP in Fluorocult LMX broth), Salmonella spp (biochemical tests and serological identification), and viable helminth eggs (HE) (settling-flotation in $\mathrm{ZnSO}_{4}$ ) as suggested by USEPA [17], Boost and Poon [25] and Bailenger [26]. All physicochemical, microbiological, and parasitological parameters were measured in triplicate.

\section{Determining digestate stability and maturity}

Digestate stability was determined according to Tigini et al. [27], in terms of $\mathrm{COD}_{\text {total }}$, $\mathrm{COD}_{\text {soluble }}$, TS, and VS. To determine digestate maturity, the level of phytotoxicity was established through germination tests, using radish ( $R$. sativus) seeds, a sensitive, fast-growing, and easy-to-handle indicator species, that exposes phytotoxic substances through their negative effects on seed germination and growth [28].

The germination tests were assessed in triplicate using their corresponding blank (pure distilled water) as a control treatment and with 100, 50, 25, and 5\% doses of each digestate diluted in distilled water [28]. Using tweezers, filter paper disks (Whatman No. 3) were placed in the Petri dishes, wherein 10 radish seeds had been placed with enough distance to account for root growth. Then, a syringe was used to saturate these filter paper disks with $4 \mathrm{~mL}$ of each digestate dilution. Next, the seeds were allowed to germinate for $4 \mathrm{~d}$ within a chamber at $25^{\circ} \mathrm{C}$.

At the end of the germination tests, the characteristics of the germinated seeds were recorded for the roots and the leaves, measuring their relative seed germination (RSG), relative root elongation (RRE), and germination index (GI) as specified by Eqs. (1)-(3), according to the methodology described by Issarakraisila et al. [28]:

$$
\begin{aligned}
& R S G=\frac{\text { No.of seeds germinated in the dilution }}{\text { No.of seeds germinated in the blank }} \times 100 \\
& R R E=\frac{\text { Average root length in the dilution }(\mathrm{mm})}{\text { Average root length in the blank }(\mathrm{mm})} \times 100 \\
& G I=\frac{R S G \times R R E}{100}
\end{aligned}
$$

To assess the phytotoxicity levels, the results obtained were analyzed considering that: (i) GI values $\leq 50 \%$ indicate a strong presence of phytotoxic substances, (ii) GI values between 50 and $80 \%$ indicate moderate presence of phytotoxic substances [28], (iii) GI values exceeding $80 \%$ indicate a positive effect, and (iv) GI values exceeding $120 \%$ evidence bio stimulation effects.

To complement the phytotoxicity analysis, bicarbonate alkalinity (BA), VFA, and $\mathrm{UV}_{254}$ absorbance were 
quantified for the measurement of humic (HA) and fulvic acids (FA) at 50, 25, and 5\% treatments. HA was measured at a wavelength between 200 and $400 \mathrm{~nm}$, an absorbance $>2.5 \mathrm{~cm}^{-1}$, FA between 270 and $330 \mathrm{~nm}$, and absorbance ranging between 0.6 and $3.0 \mathrm{~cm}^{-1}$. These tests excluded the $100 \%$ proportion because it could lead to an overestimation of the results regarding HA and FA presence [29].

\section{Statistical analysis}

To assess the influence of each digestate dose on RSG, RRE, and GI, a statistical analysis was performed using the $\mathrm{R}$ Statistical Computing software version $3.6 .5^{\circ}$ to determine the existence of significant statistical differences $(p<0.05)$. In addition, a one-way analysis of variance (ANOVA) was performed and the post-ANOVA test was applied (Tukey: $p<0.05$ ) to determine any significant differences between the examined treatments.

\section{Results and discussion}

Physicochemical, microbiological, and parasitological characterization of digestates

Table 1 below reports the characterization results for the digestates assessed and the values from the different standards used as benchmark.

Regarding $\mathrm{pH}$, the values are within the range established as per NTC 5167 [18] for all digestates. While D2 exhibited acidic characteristics, D1 and D3 displayed alkaline characteristics. This is because of the type of process and environmental conditions of each of the reactors and is related to the BA concentrations $(>1000$ $\mathrm{mg} \mathrm{L}^{-1}$ ) for methanogenic digestates (D1 and D3) and their absence in acidogenic digestates (D2) [30]. These characteristics are critical from the standpoint of digestate use, since they determine its potential applicability in acidic or alkaline soils [16].

In Colombia, acidic soils represent $85 \%$ of all agricultural lands [31], which indicates greater potentiality for

Table 1 Physicochemical, microbiological, and parasitological characterization of digestates

\begin{tabular}{|c|c|c|c|c|c|c|c|c|}
\hline \multirow[t]{2}{*}{ Parameter } & \multicolumn{3}{|l|}{ Value } & \multirow{2}{*}{$\begin{array}{l}\text { NTC } \\
5167\end{array}$} & \multirow[t]{2}{*}{ NU } & \multirow[t]{2}{*}{$N C^{a}$} & \multirow[t]{2}{*}{ NI } & \multirow[t]{2}{*}{ Nlt } \\
\hline & D1 & D2 & D3 & & & & & \\
\hline \multicolumn{9}{|l|}{ Physicochemicals } \\
\hline $\mathrm{pH}$ & $6.77-6.83$ & $4.57-4.67$ & $8.56-8.70$ & $4-9$ & N.E & N.E & N.E & N.E \\
\hline $\mathrm{BA}\left(\mathrm{mg} \mathrm{L}^{-1}\right)$ & $1052 \pm 120$ & $0.00 \pm 0.0$ & $1666 \pm 350$ & N.E & N.E & N.E & N.E & N.E \\
\hline Moisture (\%) & $92.5 \pm 7.2$ & $93.0 \pm 5.3$ & $93.1 \pm 6.3$ & 35 & N.E & N.E & N.E & N.E \\
\hline $\mathrm{CEC}\left(\mathrm{cmol} \mathrm{kg}{ }^{-1}\right)$ & $20.90 \pm 1.2$ & $70.7 \pm 5.5$ & $51.8 \pm 6.2$ & $\geq 30$ & N.E & N.E & N.E & N.E \\
\hline $\mathrm{TOC}\left(\mathrm{g} \mathrm{kg}^{-1}\right)$ & $38 \pm 3$ & $37 \pm 1$ & $40 \pm 2$ & $\geq 15$ & N.E & N.E & N.E & N.E \\
\hline $\mathrm{TN}\left(\mathrm{g} \mathrm{kg}^{-1}\right)$ & $6.9 \pm 1.2$ & $14.3 \pm 3.2$ & $14.6 \pm 3.3$ & $>1.0$ & N.E & N.E & N.E & 1.5 \\
\hline $\mathrm{TP}\left(\mathrm{g} \mathrm{kg}^{-1}\right)$ & $7.2 \pm 1.5$ & $1.4 \pm 0.5$ & $10.5 \pm 1.7$ & $>1.0$ & N.E & N.E & N.E & 0.4 \\
\hline $\mathrm{AA}\left(\mathrm{mg} \mathrm{L}^{-1}\right)$ & $5090 \pm 250$ & $2422 \pm 150$ & $3501 \pm 178$ & N.E & N.E & N.E & N.E & N.E \\
\hline $\operatorname{PrA}\left(\mathrm{mg} \mathrm{L}^{-1}\right)$ & $1062 \pm 168$ & $1156 \pm 148$ & $1039 \pm 201$ & N.E & N.E & N.E & N.E & N.E \\
\hline $\mathrm{PA}\left(\mathrm{mg} \mathrm{L}^{-1}\right)$ & $178 \pm 60$ & $546 \pm 25$ & $122 \pm 17$ & N.E & N.E & N.E & N.E & N.E \\
\hline $\mathrm{OA}\left(\mathrm{mg} \mathrm{L}^{-1}\right)$ & $107 \pm 25$ & $546 \pm 45$ & $61 \pm 24$ & N.E & N.E & N.E & N.E & N.E \\
\hline $\mathrm{Cu}\left(\mathrm{mg} \mathrm{kg}^{-1}\right)$ & $31.7 \pm 0.4$ & $60.6 \pm 0.8$ & $148.3 \pm 0.7$ & N.E & 1500 & 1750 & 149 & 230 \\
\hline $\mathrm{Cd}\left(\mathrm{mg} \mathrm{kg}^{-1}\right)$ & $0.1 \pm 0.1$ & $0.1 \pm 0.1$ & $0.2 \pm 0.1$ & N.E & 39 & 40 & 1.3 & 1.5 \\
\hline $\mathrm{Cr}\left(\mathrm{mg} \mathrm{kg}^{-1}\right)$ & $11.2 \pm 0.2$ & $25.9 \pm 0.2$ & $52.8 \pm 0.2$ & 1200 & 1200 & 1500 & 92 & 0.5 \\
\hline $\mathrm{Zn}\left(\mathrm{mg} \mathrm{kg}^{-1}\right)$ & $202 \pm 25$ & $1055 \pm 80$ & $1177 \pm 61$ & N.E & 2800 & 2800 & 397 & 600 \\
\hline $\mathrm{Hg}\left(\mathrm{mg} \mathrm{kg}^{-1}\right)$ & $<0.01$ & $<0.01$ & $<0.01$ & 17 & 17 & 20 & 0.4 & 105 \\
\hline $\mathrm{Mo}\left(\mathrm{mg} \mathrm{kg}^{-1}\right)$ & $<2.3$ & $<2.3$ & $<2.3$ & N.E & 75 & 75 & N.E & N.E \\
\hline $\mathrm{Ni}\left(\mathrm{mg} \mathrm{kg}^{-1}\right)$ & $7.8 \pm 1.1$ & $12.9 \pm 6.5$ & $32.8 \pm 2.5$ & 420 & 420 & 420 & 56 & 100 \\
\hline $\mathrm{Pb}\left(\mathrm{mg} \mathrm{kg}^{-1}\right)$ & $3.6 \pm 3.5$ & $6.5 \pm 2.5$ & $22.8 \pm 2.9$ & 300 & N.E & 400 & 149 & 140 \\
\hline $\mathrm{Se}\left(\mathrm{mg} \mathrm{kg}^{-1}\right)$ & $<0.01$ & $<0.01$ & $<0.01$ & N.E & 36 & 100 & N.E & N.E \\
\hline \multicolumn{9}{|l|}{ Microbiological and Parasitological } \\
\hline $\mathrm{FC}\left(\mathrm{CFU} 100 \mathrm{~mL}^{-1}\right)$ & $0 \pm 0.0$ & $0 \pm 0.0$ & $0 \pm 0.0$ & $<1000$ & $<1000$ & $<2 \mathrm{E}+6$ & 1000 & N.E \\
\hline Salmonella spp. (CFU $25 \mathrm{~g}^{-1}$ ) & A & A & A & A & $<3 \mathrm{NMP} 4 \mathrm{~g}^{-1}$ & $<1 \mathrm{E}+3$ & A & A \\
\hline $\mathrm{HE}\left(\mathrm{HE} \mathrm{g}{ }^{-1}\right)$ & $16 \pm 1.0$ & $6 \pm 1.0$ & $0 \pm 0.0$ & N.E & $<1.0$ & $<10$ & N.E & N.E \\
\hline
\end{tabular}

Parameters measured on a dry matter; A Absence, NTC Colombian Technical Norm, NC Colombian Standards, NU US Standards, NI Irish Standards, NIt Italian Standards, N.E Not Required ${ }^{\mathrm{a}}$ Class B. Source: $[12,13,17,18,21]$ 
D1 and D3 application. In addition, the presence of BA can improve the agricultural potential of acidic soils ( $\leq 5.5$ units), considering that these soils can exhibit soluble $\mathrm{Al}^{3+}$ and $\mathrm{Mn}^{2+}$ concentrations, which can reach toxic levels for crops and affect the microbial consortiums and the activities of the microorganisms that mineralize organic matter and perform the microbial transformation of nitrogen and sulfur [32].

Regarding moisture, an excess in soil water contents displaces oxygen, generating anaerobic conditions and causing aerobic microorganisms to start using other elements, such as $\mathrm{N}, \mathrm{Mn}$, and S, to fulfill their life cycle. Therefore, the availability of these crucial macronutrients for root growth and cytokine synthesis is decreased [33]. Since the values reported for all digestates is higher than the recommended value (35\%), the application of moisture reduction processes, such as thermal or chemical pretreatments, which can even contribute to digestate sanitation by reducing pathogenic microorganisms without affecting their soil improvement capacities, is highly recommended [16].

CEC is related to the gradual release of nutrients to crops and the retention of potential pollutants that are in the soil [1]. D1 reported a lower CEC than the value established in NTC 5167 [18], while the D2 and D3 values are within the range established therein, and are similar to values reported by Voelkner et al. [34], who mention that CEC values depend on the content of organic matter and hydroxides (particularly from the $\mathrm{COOH}$ and $-\mathrm{OH}$ groups), since they interact with the interchangeable cations in the soil [16].

For D1, its low CEC may be associated with the operating OLR reported by the reactor $\left(6.0 \mathrm{~kg} \mathrm{VS} \mathrm{m}^{-3} \mathrm{~d}^{-1}\right)$, which led to an overload and, in turn, to the presence of non-mineralized organic matter [4].

Overall, TOC, TN and TP meet the minimum requirements for organic amendments used in crops, established in NTC 5167 [18], wherein the potential contribution from digestates in terms of organic matter and nutrients is emphasized. D3 reported the highest concentrations of TN and TP, followed by D1 and D2. The values found are also similar to other digestates obtained through the AD of FW, such as those reported by Drosg et al. [35] (4.93 $\mathrm{g} \mathrm{N} \mathrm{kg}^{-1}$ and $0.90 \mathrm{~g} \mathrm{P} \mathrm{kg}^{-1}$ ).

These characteristics are especially interesting since about $40 \%$ of Colombian soils evidence erosion conditions, with one of their preceding aspects being the shortage of organic matter, and the presence of these nutrients can bring about a reduction in soil temperatures fluctuations due to the fact that they promote rapid seed germination, which leads to cohesion between the soil and the root of the plant [19]. In this study, the $\mathrm{TOC}$, TN, and TP values agree with the findings reported by Tambone et al. [36] which assert that high contents of these elements are commonly found in digestates.

With respect to heavy metals, $\mathrm{Zn}$ was the only metal that exceeded the Irish $\left(397 \mathrm{mg} \mathrm{kg}^{-1}\right.$ ) and Italian (600 $\mathrm{mg} \mathrm{kg}^{-1}$ ) standards in D2 and D3, although fully complying with the concentration levels provisioned in the NTC 5167 standards, Decree 2187, and the USEPA Part 503 standard.

D1 did not report an excess of $\mathrm{Zn}$ since the organic compounds produced in single-stage reactors generate low metal accumulation rates [37]. Nevertheless, although regulations regarding this metal are usually based on total concentrations, its ecotoxicity depends not only on total concentrations but also on its speciation. In fact, speciation determines its bioavailability [38], because this element exhibits very low mobility and tends to build up in plant roots and withered leaves [39].

Another interesting aspect in terms of digestate characteristics is the presence and quantity of VFAs, which influences the volatilization of the nitrogen levels available at concentrations ranging from 1100 to $4900 \mathrm{mg}$ $\mathrm{L}^{-1}$, thus, improving crop assimilation [40].

In addition, we must also determine what type of acid (short or long chain) is generated, to establish whether its potential effect on the crop is either toxic or stimulating [11]. Both aspects are subject to the dynamics of the organic matter transformation process (composting, $\mathrm{AD}$, and vermicomposting) [10].

Within this context, Samaniego and Pedroza-Sandoval [11] further claim that VFAs, such as AA and PrA, exhibit properties against the phytopathogenic organisms in the soil (concentrations $>307 \mathrm{mg} \mathrm{L}^{-1}$ ). In fact, these organisms die in just minutes, because the VFAs modify the osmotic gradient of the cell membrane of these microorganisms [34]. This effect was evidenced in this study, wherein the microbiological characterization denoted an absence of FCs and Salmonella spp. in the digestates, as well as high VFA levels (AA: D1: $5090 \mathrm{mg} \mathrm{L}^{-1}$, D2: $2422 \mathrm{mg} \mathrm{L}^{-1}$, and D3: $3501 \mathrm{mg} \mathrm{L}^{-1}$ and for PrA: D1: $1062 \mathrm{mg} \mathrm{L}^{-1}$, D2: $1156 \mathrm{mg}$ $\mathrm{L}^{-1}$, and D3: $\left.1039 \mathrm{mg} \mathrm{L}^{-1}\right)$. Furthermore, since PA and OA are considered phytostimulants [29], their presence must be assessed in the digestates.

However, it is necessary to consider any negative effects that these types of acids may have on microorganisms which are beneficial for crops, since some are tolerant to certain concentrations or use this type of compound as a carbon source.

The infectious properties of HE can be preserved between 20 months and $6 \mathrm{yr}$ [41]. In this study, D1 reported a higher level of HE than D2 (60\% reduction) and D3 (total inactivation). This behavior is also related to the antiparasitic effect from the VFAs and the double exposure of these compounds experienced by the digested material in the two-stage configuration. 
These two conditions also contribute to the complete obliteration of the protective membrane surrounding the parasites [11]. Furthermore, Timper [42] determined that nematodes like Meloidogyne spp. are completely removed at AA concentrations of $331 \mathrm{mg} \mathrm{L}^{-1}$.

In summary, in terms of physicochemical, microbiological, and parasitological characteristics and in accordance with Colombian (NTC 5167-2011 and Decree 1287-2014) and American (EPA 503-1994) standards, the two-stage AD-FW configuration favored digestate features, with D3 exhibiting the best quality, not only in terms of organic matter and nutrients but also in terms of metal contents, low FC loads, and the absence of Salmonella spp. and HE. Hence, D3 was classified as a type B material, which could be used as a soil improver or organic fertilizer for crops that require subsequent processing (i.e., corn, sugar cane, wheat, among others).

Conversely, although D1 and D2 report contents of organic matter and nutrients that would allow them to be potentially used as amendments, the presence of $\mathrm{HE}$ dictates the implementation of sanitation strategies. Furthermore, since D2 reports a low pH level, it may only be used in alkaline soils or requires $\mathrm{pH}$ and alkalinity adjustments [16]. In all cases, the moisture content of these digestates should be reduced before they can be used for agricultural purposes.

\section{Digestate stability}

Regarding the stability parameters of the digestates, Table 2 presents the parameters related to stability.

Regarding the $C O D_{\text {total }}$ and $C O D_{\text {soluble }}$ values, the high concentrations reported are possibly associated with the VFAs and the preceding HA materials (lignin and hemicellulose, among others, found in the FW), which biostimulate plant growth due to stable molecules such as lignin and proteins [11]. Notwithstanding, the concentrations reported for D2 and D3 are lower than those reported for D1, which is associated with a more efficient organic matter transformation in the two-stage configuration [23].

Akhiar et al. [43] sustain that reducing organic loads by more than $50 \%$ guarantees stable conditions for the organic matter; however, there is no agreement in the proposed values to secure a stable digestate in terms of COD. In addition, Tigini et al. [27] claim that the lower

Table 2 Stability parameters for the digestates assessed

\begin{tabular}{lllll}
\hline Parameter & D1 & D2 & D3 & Unit \\
\hline COD $_{\text {total }}$ & $69.07 \pm 1.68$ & $14.17 \pm 7.72$ & $30.87 \pm 1.70$ & $\mathrm{~g} \mathrm{~L}^{-1}$ \\
COD $_{\text {soluble }}$ & $57.81 \pm 0.30$ & $11.70 \pm 0.76$ & $25.28 \pm 0.49$ & $\mathrm{~g} \mathrm{~L}^{-1}$ \\
TS & $44.90 \pm 3.30$ & $7.98 \pm 0.60$ & $33.38 \pm 1.64$ & $\mathrm{~g} \mathrm{~L}^{-1}$ \\
VS & $29.30 \pm 0.40$ & $6.82 \pm 0.65$ & $18.91 \pm 0.30$ & $\mathrm{~g} \mathrm{~L}^{-1}$ \\
\hline
\end{tabular}

the COD concentration, the higher the digestate stability.

The VS/TS ratio has often been considered as an indicator variable of stability [43]. In this regard, MVCT [21] mention that a higher content of organic matter (represented by a higher VS/TS ratio) reflects lower stability.

Conversely, Akhiar et al. [43] and Peng et al. [6] establish a $0.37-0.77$ range for stable digestates, emphasizing that the content of organic matter must be related to the presence of substances such as VFAs and lignocellulosic material. In this study, D3 reported the lowest VS/TS ratio (0.57) followed by D1 (0.65). Still, D2 reported a much higher value $(0.85)$, which indicates that D3 is the least active digestate of the three and therefore, the most stable [21].

In terms of digestate generation, Fig. 1 denotes VS balances for each reactor, wherein the two-stage configuration reduces VS content by $80 \%$ (35\% less digested material produced during the $\mathrm{AD}$ ) as opposed to the single-stage configuration. This may be attributed to the greater transformation of organic matter from the substrate into biogas (approximately 30\%) reported for the two-stage configuration. Within this context, ParraOrobio et al. [23] agree that two-stage reactors remove a higher amount of VS and COD, as reflected by the lower quantity and greater stability of the digestate produced.

These results suggest that the two-stage AD-FW, in addition to being more favorable than the single-stage configuration in terms of generating greater substrate degradation by improving the hydrolysis process [23], is also more favorable in terms of higher digestate stability, which is consistent with the findings reported. During its decomposition processes within the soil, this material, as an organic matter source, can contribute to the generation of a colloidal humus, thus, providing structure and porosity to the soil [6].

\section{Digestate maturity}

Table 3 lists the resulting germination and physicochemical parameters values for the different digestates assessed.

As it can be observed, the RSG, RRE, and GI values reported an inverse relationship with the doses assessed for all digestates. In this sense, the 5\% dose produced better results for the variables associated with phytotoxicity, which is confirmed from the statistical point of view, where significant differences were found among all digestates and doses $(p<0.05)$ and among D1, D2, and D3 doses $(p<0.05)$, confirming, from the Tukey test, that the $5 \%$ dose reported the biggest differences in these indicators for all digestates.

This is consistent with the findings reported by $\mathrm{Da}$ Ros et al. [22], who achieved better germination rates and physicochemical properties with doses under $12.5 \%$, 


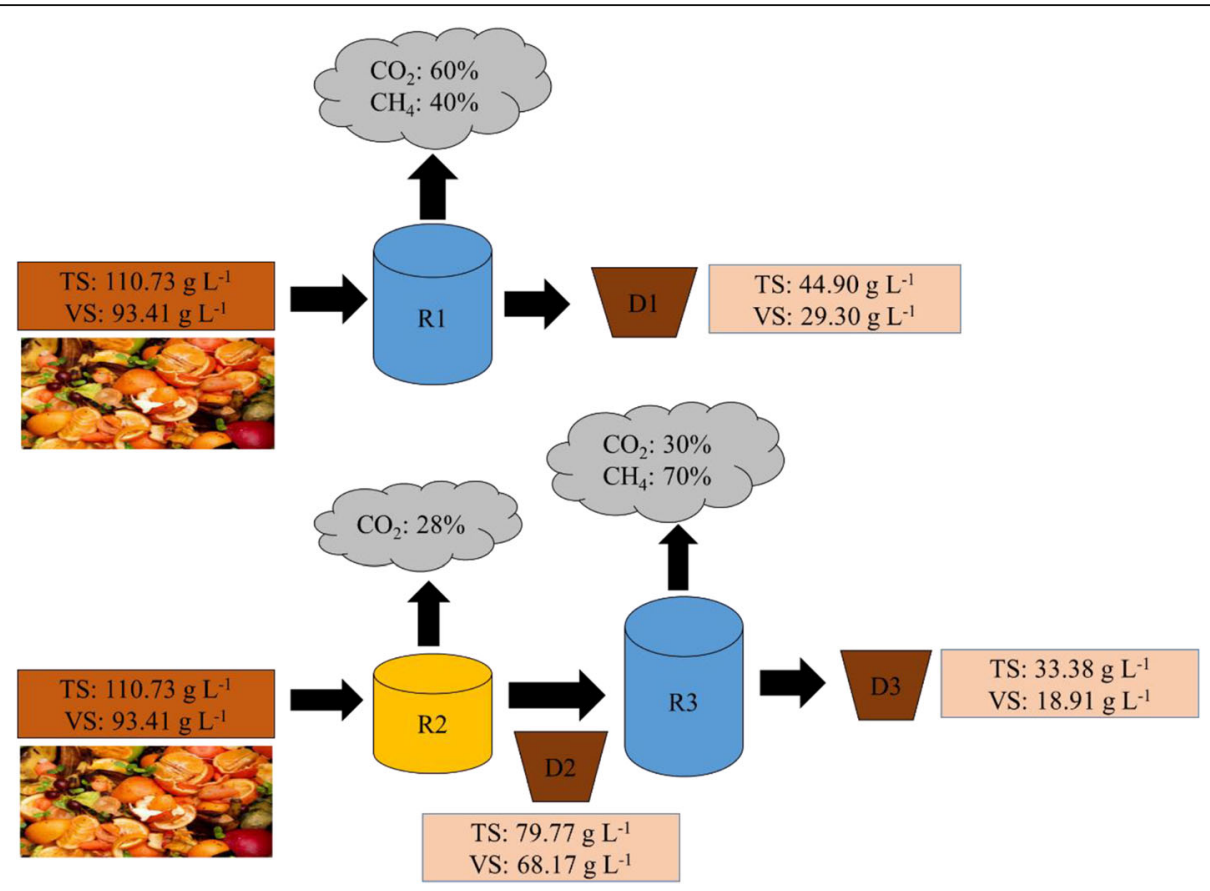

Fig. 1 Solids stream in single-stage and two-stage configurations

as these conditions allow nutrients to be assimilated more easily by the plant, and in turn, dilute potential inhibitory substances for the root system [33].

At concentrations of 100 and 50\%, the RSG value was $0 \%$. The RSG value increased for the $25 \%$ concentration (14-34\%), however the digestates at this dose had not yet completed their maturity stage, and, therefore, contained phytotoxic substances, such as VFAs $(>950 \mathrm{mg}$ $\mathrm{L}^{-1}$ ) and organic compounds that had not been fully metabolized at that point [11].

Although some authors point out the beneficial effect of VFAs in the soil, the findings described here may be related to the fact that soil is not used in the phytotoxicity test, an element that reduces the potential of VFAs due to the interaction of the abiotic and biotic components that constitute them [11].

For the 5\% doses, the RSG values ranged between 70 and $95 \%$, similar to those by Bona et al. [44], who concluded that as diluted digestate doses decrease, germination increases. This is attributed to an increase in organic carbon availability as organic carbon exhibits a tendency to form compounds with potential contaminants, thus reducing the effects from any phytotoxic substances found in digestates.

Table 3 Germination, $\mathrm{pH}, \mathrm{BA}$, and VFAs test results

\begin{tabular}{|c|c|c|c|c|c|c|c|}
\hline $\bar{D}$ & Do (\%) & RSG (\%) & RRE (\%) & GI (\%) & $\mathrm{pH}$ & $\mathrm{BA}\left(\mathrm{mg} \mathrm{L}^{-1}\right)$ & VFAs $\left(\mathrm{mg} \mathrm{L}^{-1}\right)$ \\
\hline \multirow[t]{4}{*}{ D1 } & 100 & 0 & 0 & 0 & $8.07-8.08$ & $1053 \pm 43$ & $8581 \pm 2627$ \\
\hline & 50 & 0 & 0 & 0 & $8.03-8.07$ & $543 \pm 2$ & $4479 \pm 185$ \\
\hline & 25 & $33 \pm 30$ & $3 \pm 3$ & $1 \pm 1$ & $8.07-8.17$ & $305 \pm 39$ & $2501 \pm 37$ \\
\hline & 5 & $70 \pm 17$ & $100 \pm 2$ & $70 \pm 16$ & $8.19-8.21$ & $61 \pm 1$ & $640 \pm 9$ \\
\hline \multirow[t]{4}{*}{ D2 } & 100 & 0 & 0 & 0 & $4.68-4.70$ & 0 & $8200 \pm 781$ \\
\hline & 50 & 0 & 0 & 0 & $4.74-4.76$ & 0 & $6609 \pm 126$ \\
\hline & 25 & $14 \pm 4$ & $31 \pm 8$ & $4 \pm 1$ & $4.75-4.77$ & 0 & $4310 \pm 30$ \\
\hline & 5 & $97 \pm 6$ & $100 \pm 2$ & $73 \pm 2$ & $5.04-5.06$ & 0 & $1175 \pm 140$ \\
\hline \multirow[t]{4}{*}{ D3 } & 100 & 0 & 0 & 0 & $9.30-9.32$ & $1649 \pm 23$ & $3626 \pm 137$ \\
\hline & 50 & 0 & 0 & 0 & $9.14-9.16$ & $788 \pm 3$ & $1734 \pm 5$ \\
\hline & 25 & $28 \pm 25$ & $6 \pm 6$ & $2 \pm 2$ & $9.11-9.13$ & $445 \pm 5$ & $921 \pm 37$ \\
\hline & 5 & $95 \pm 3$ & $207 \pm 19$ & $195 \pm 36$ & $8.56-8.60$ & $92 \pm 3$ & $127 \pm 0$ \\
\hline
\end{tabular}


With relation to RRE, the 5\% dose also reached values above $90 \%$, which may indicate that the doses of 100,50 , and $25 \%$ may exhibit moderately phytotoxic metabolites or an imbalance of the buffer capacity within the medium, as reflected in the high VFA concentrations. Although this does not prevent the seed from germinating (as evidenced by the RSG values), it can constrain root development as roots may be exposed to stress from organic acid activity [11]. This phenomenon is similar to those results reported by Mupambwa et al. [45], who achieved a 47-97\% RRE value using different cultures at digestate doses under $10 \%$.

Regarding the GI, for both D1 and D2, the 5\% dose results indicate a moderate presence of phytotoxic substances $(50 \%<\mathrm{GI}<80 \%)$, which means that they had not yet reached maturity. Conversely, the $5 \%$ doses yielded better maturity levels with some biostimulation signs for D3 (GI > 120\%). Hence, the results reported for both D1 and D2 suggest the existence of organic matter that partially stimulates plant growth, as well as the presence of phytotoxic compounds [28].

Furthermore, Sipkova et al. [46] specify that plants assimilate FAs better, since HAs are soluble in an alkaline aqueous media but insoluble in water under acidic conditions, while FAs are the soluble fraction at all $\mathrm{pH}$ values. In addition, FAs stimulate plant root systems. Figure 2 below denotes the presence of HAs and FAs in terms of $\mathrm{UV}_{254}$ absorbance, which is typically associated with the presence of natural organic matter, such as these organic compounds [29].

The observed behavior is in accordance with the findings reported by Zheng et al. [29] who claim that these compounds are commonly found in digestates, since FW contains substrates with an important fraction of lignocellulosic material, which fosters the formation of these organic compounds. Therefore, $\mathrm{UV}_{254}$ values may potentially identify agriculturally viable organic compounds that originate as AD-FW by-products, such as digestates.

As for D3, this digestate may have exhibited better characteristics than the others due to its concentrations of PA, OA, and HA substances that, in addition to being phytostimulants, also serve as electron acceptors that improve effectiveness and accelerate organic matter biodegradation through microbial action. These results are also associated with the presence of FAs as evidenced in the second peak from Fig. 2 representing D3.

The aforementioned phenomenon actually constitutes an additional advantage when using these digestates as partial replacement for chemical fertilizers, since these compounds are commonly added to the soil through chemical inputs. Furthermore, most agricultural soils in Colombia report higher a HA than FA content. Overall, $5 \%$ D3 is the digestate that fosters optimal development of radish ( $R$. sativus) crops due its nutrient availability and buffer capacity, which did not affect the root system of the plant, as well as for the presence of humic acids and, in particular FA.

\section{Conclusions}

The anaerobic digestion of food waste confirms the possibility of obtaining highly agriculturally viable digestates. In this sense, the best quality digestates were produced through the anaerobic two-stage configuration. The digestate from acetogenic-methanogenic reactor (D3) was much better due to its content of essential macronutrients, such as nitrogen and phosphorus, exceeding the acceptable metal levels by $1 \%$, in addition to
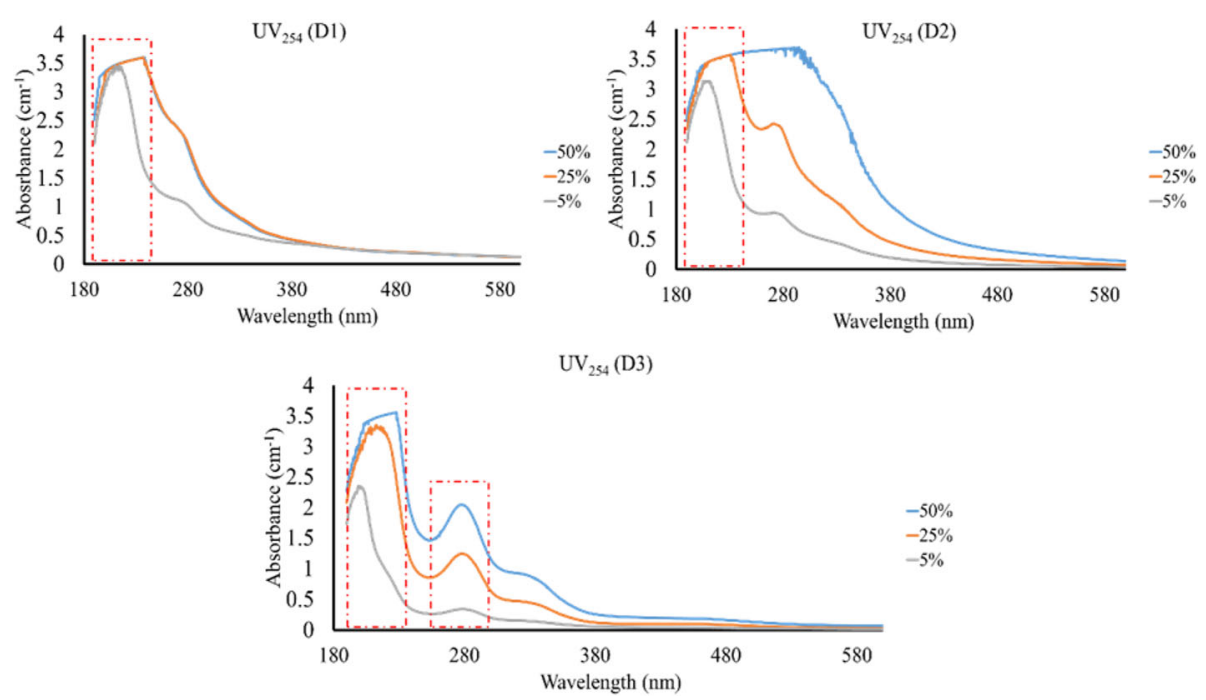

Fig. $2 U_{254}$ curves used to identify $H A$ and FA at 50, 25, and 5\% doses for each digestate assessed 
the presence of short-chain fatty acids with antimicrobial effects, such as acetic and propionic acids, and longchain volatile fatty acids, such as palmitic and oleic, which exert a phytostimulating action.

D3 evidenced the best characteristics among the digestates assessed (best stability and maturity properties in terms of VS/TS content, COD, and GI, with values exceeding $120 \%$ at a $5 \%$ dose), which favors biostimulation for growing radish (Raphanus sativus) crops. This biostimulation is also attributed to its nutrient content and the presence of humic and fulvic acids. D3 presented class B material conditions. However, all digestates require additional treatments to reduce the moisture content by about $35 \%$, as established in the agriculture use standards and regulations that govern these products.

It is necessary to recommend revision and adjustment the Colombian standard in terms of moisture content, since it is difficult to achieve moisture percentages of $35 \%$ through anaerobic digestion of food waste without resorting to pretreatment.

The dilution of the digestate to $5 \%$ with the water used in the irrigation processes of crops on a larger scale should be evaluated, analyzing effects in the field and considering agriculture operational factors. Likewise, the use of other types of water as dilution agents for digestates than can also provide nutrients, such as wastewater, should also be evaluated, whilst considering their prior physicochemical characterization.

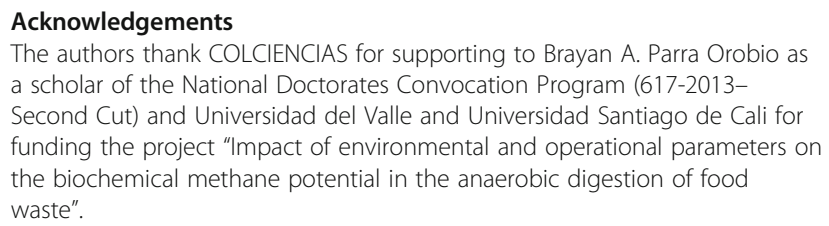
a scholar of the National Doctorates Convocation Program (617-2013Second ( Cut) and Universidad del Valle and Universidad Santiago de Cali for funding the project "Impact of environmental and operational parameters on the biochemical methane potential in the anaerobic digestion of food waste".

\section{Authors' contributions}

B. A. Parra-Orobio (BAPO), A. Vidal-Pérez (APV), L. F. Marmolejo-Rebellón (LFMR) and P. Torres-Lozada (PTL) were responsible for the conceptualization and design of the study. M. Rotavisky-Sinisterra (MRS) and BAPO worked in the acquisition and interpretation of data through field and laboratory work. BAPO drafted the article and LFMR, APV and PTL revised it critically. All authors read and approved the final manuscript.

\section{Funding}

This work was supported by Universidad del Valle and Universidad Santiago de Cali $\mathrm{Cl}-21089$

\section{Availability of data and materials}

All data generated or analysed during this study are included within the article.

\section{Declarations}

\section{Competing interests}

The authors declare they have no competing interests.

\section{Author details}

${ }^{1}$ Faculty of Engineering, Universidad del Valle, Cali 760032, Colombia.

${ }^{2}$ Faculty of Engineering, Universidad Santiago de Cali, Cali 760032, Colombia.
Received: 28 July 2020 Accepted: 23 February 2021

Published online: 04 March 2021

\section{References}

1. Foronda-Zapata K, Arias-Giraldo C, Soto-Paz J, Marmolejo-Rebellon LF, Torres-Lozada P. Effect of grass star incorporation on the composting biowaste process and on the quality of the product. Rev EIA. 2020;17:1-11 [in Spanish].

2. Reyes $G E$, Cortes JD. Intensity of fertilizer use in Latin Amaerica and the Caribbean (2006-2012). Bioagro. 2017;29:45-52 [in Spanish].

3. Ning CC, Gao PD, Wang BQ, Lin WP, Jiang NH, Cai KZ. Impacts of chemical fertilizer reduction and organic amendments supplementation on soil nutrient, enzyme activity and heavy metal content. J Integr Agr. 2017;16: 1819-31.

4. Xiao BY, Qin Y, Qu J, Chen H, Yu PF, Liu JX, et al. Comparison of single-stage and two-stage thermophilic anaerobic digestion of food waste: performance, energy balance and reaction process. Energ Convers Manage. 2018;156:215-23.

5. Panuccio MR, Papalia T, Attina E, Giuffre A, Muscolo A. Use of digestate as an alternative to mineral fertilizer: effects on growth and crop quality. Arch Agron Soil Sci. 2019;65:700-11.

6. Peng W, Pivato A, Garbo F, Wang TF. Stabilization of solid digestate and nitrogen removal from mature leachate in landfill simulation bioreactors packed with aged refuse. J Environ Manage. 2019;232:957-63.

7. Grigatti M, Barbanti L, Hassan MU, Ciavatta C. Fertilizing potential and $\mathrm{CO}_{2}$ emissions following the utilization of fresh and composted food-waste anaerobic digestates. Sci Total Environ. 2020;698:134198.

8. Pawlak-Kruczek H, Niedzwiecki L, Sieradzka M, Mlonka-Medrala A, Baranowski M, Serafin-Tkaczuk M, et al. Hydrothermal carbonization of agricultural and municipal solid waste digestates - structure and energetic properties of the solid products. Fuel. 2020;275:117837.

9. Karthikeyan OP, Trably E, Mehariya S, Bernet N, Wong JWC, Carrere H. Pretreatment of food waste for methane and hydrogen recovery: a review. Bioresour Technol. 2018;249:1025-39.

10. Prochazka P. Acute and subchronic phytotoxicity of volatile fatty acids (VFAs). [Master's Thesis]. Jyväskylä: Univ Jyväskylä; 2008.

11. Samaniego GJA, Pedroza-Sandoval A. Potential use of volatile fatty acids in soil, water and air. Terra Latino. 2013;31:155-63 [in Spanish].

12. PI. Revision of the Regulation on Fertilizers. Rome: Italian Parliament; 2010 [in Italian]. https://www.camera.it/parlam/leggi/deleghe/testi/10075dl.htm.

13. IrBEA. A Draft Industry Standard for Anaerobic Digestion Digestate. Dublin: Irish Bioenergy Association; 2012.

14. MP. Royal Decree 506/2013 of June 28 on Fertilizer Products. Madrid: Ministry of the Presidency; 2013 [in Spanish].

15. BSI. Specification for Whole Digestate, Separated Liquor and Separated Fibre Derived from the Anaerobic Digestion of Source-segregated Biodegradable Materials. London: British Standards Institution; 2014.

16. Penarete MW, Silva-Leal J, Urrutia CN, Daza TM, Torres-Lozada P. Effect of biosolids application on soil physical properties of a sugarcane crop. Acta Agron. 2013:62:251-60 [in Spanish].

17. USEPA. Process design manual, land application of sewage sludge and domestic septage. Washington, DC: US Environmental Protection Agency; 1995.

18. ICONTEC. Agricultural Industry Products. Organic Products Used as Fertilizers and Soil Amendments. Bogota: Colombian Institute of Technical Standards and Certification; 2011 [in Spanish].

19. Torres-Lozada P, Silva-Leal JA, Parra-Orobio BA, Ceron-Castro V, Madera-Parra CA. Influence of biosolids aplication on soil, plant and quality and productivity of sugarcane crop. Rev UDCA. 2015;18:69-79 [in Spanish]

20. Martí-Herrero J. Latin America expiriencies in the democratistion of biodigesters. Contributions to Ecuador. Copenhagen: Climate Technology Centre and Network; 2019.

21. MVCT. By Which Criteria are Established for the Use of Biosolids Generated in Municipal Wastewater Treatment Plants. Bogota: Ministry of Housing, City and Territory; 2014 [in Spanish]. http://parquearvi.org/wp-content/uploads/2 016/11/Decreto-1287-de-2014.pdf.

22. Da Ros C, Libralato G, Ghirardini AV, Radaelli M, Cavinato C. Assessing the potential phytotoxicity of digestate from winery wastes. Ecotox Environ Safe. 2018;150:26-33

23. Parra-Orobio BA, Donoso-Bravo A, Torres-Lozada P. Energy balance and carbon dioxide emissions comparison through modified anaerobic 
digestion model No 1 for single-stage and two-stage anaerobic digestion of food waste. Biomass Bioenerg. 2020;142:105814.

24. APHA. Standard methods for examination of water and wastewater. 21st. Washington, DC: American Public Health Association; 2005.

25. Boost MV, Poon CS. The effect of a modified method of lime-stabilisation sewage treatment on enteric pathogens. Environ Int. 1998;24:783-8.

26. Bailenger J. Mechanisms of parasitical concentration in coprology and their practical consequences. J Am Med Technol. 1979;41:65-71.

27. Tigini V, Franchino M, Bona F, Varese GC. Is digestate safe? A study on its ecotoxicity and environmental risk on a pig manure. Sci Total Environ. 2016; 551:127-32.

28. Issarakraisila M, Ma QF, Turner DW. Photosynthetic and growth responses of juvenile Chinese kale (Brassica oleracea var. alboglabra) and Caisin (Brassica rapa subsp parachinensis) to waterlogging and water deficit. Sci HorticAmsterdam. 2007;111:107-13.

29. Zheng W, Lu F, Phoungthong K, He PJ. Relationship between anaerobic digestion of biodegradable solid waste and spectral characteristics of the derived liquid digestate. Bioresour Technol. 2014;161:69-77.

30. Kang J, Kwon G, Nam JH, Kim YO, Jahng D. Carbon dioxide stripping from anaerobic digestate of food waste using two types of aerators. Int J Environ Sci Te. 2017;14:1397-408.

31. Casierra-Posada F, Aguilar-Avedano OE. Stress for aluminum in plants: reactions in the soil, symptoms in plants and amelioration possibilities. A review. Rev Colom Cienc Hortic. 2007; 1:246-57 [in Spanish].

32. Delgado Huertas $\mathrm{H}$, Rangel JA, Silva Parra A. Chemical characterization of soil fertility in production systems of a flat high plateau, Meta, Colombia. Rev Luna Azul. 2018;46:54-69 [in Spanish].

33. Jimenez SJC, Moreno FLP, Magnitskiy S. Plant responses to stress due to flooding. A review. Rev Colom Cienc Hortic. 2012;6:96-109 [in Spanish].

34. Voelkner A, Holthusen D, Horn R. Determination of soil dispersion caused by anaerobic digestates: interferences of $\mathrm{pH}$ and soil charge with regard to soil texture and water content. J Soil Sediment. 2015;15:1491-9.

35. Drosg B, Fuchs W, Al Seadi T, Madsen M, Linke B. Nutrient recovery by biogas digestate processing. Paris: IEA Bioenergy; 2015.

36. Tambone F, Orzi V, Zilio M, Adani F. Measuring the organic amendment properties of the liquid fraction of digestate. Waste Manage. 2019;88:21-7.

37. Knoop C, Dornack C, Raab T. Effect of drying, composting and subsequent impurity removal by sieving on the properties of digestates from municipal organic waste. Waste Manage. 2018;72:168-77.

38. Nolan AL, Lombi E, McLaughlin MJ. Metal bioaccumulation and toxicity in soils - why bother with speciation? Aust J Chem. 2003;56:77-91.

39. Le Bars M, Legros S, Levard C, Chaurand P, Tella M, Rovezzi M, et al. Drastic change in zinc speciation during anaerobic digestion and composting: instability of nanosized zinc sulfide. Environ Sci Technol. 2018;52:12987-96.

40. Fagbohungbe MO, Onyeri C, Adewale C, Semple KT. The effect of acidogenic and methanogenic conditions on the availability and stability of carbon, nitrogen and phosphorus in a digestate. J Environ Chem Eng. 2019; 7:103138.

41. Seruga P, Krzywonos M, Paluszak Z, Urbanowska A, Pawlak-Kruczek H, Niedzwiecki $L$, et al. Pathogen reduction potential in anaerobic digestion of organic fraction of municipal solid waste and food waste. Molecules. 2020; 25:275.

42. Timper P. Conserving and enhancing biological control of nematodes. J Nematol. 2014;46:75-89.

43. Akhiar A, Battimelli A, Torrijos M, Carrere H. Comprehensive characterization of the liquid fraction of digestates from full-scale anaerobic co-digestion. Waste Manage. 2017:59:118-28.

44. Bona D, Beggio G, Weil T, Scholz M, Bertolini S, Grandi L, et al. Effects of woody biochar on dry thermophilic anaerobic digestion of organic fraction of municipal solid waste. J Environ Manage. 2020;267:110633.

45. Mupambwa HA, Namwoonde AS, Liswaniso GM, Hausiku MK, Ravindran B. Biogas digestates are not an effective nutrient solution for hydroponic tomato (Lycopersicon esculentum L.) production under a deep water culture system. Heliyon. 2019;5:e02736.

46. Sipkova A, Szakova J, Hanc A, Tlustos P. Mobility of mercury in soil as affected by soil physicochemical properties. J Soil Sediment. 2016;16:2234-41.

\section{Publisher's Note}

Springer Nature remains neutral with regard to jurisdictional claims in published maps and institutional affiliations.

\section{Ready to submit your research? Choose BMC and benefit from:}

- fast, convenient online submission

- thorough peer review by experienced researchers in your field

- rapid publication on acceptance

- support for research data, including large and complex data types

- gold Open Access which fosters wider collaboration and increased citations

- maximum visibility for your research: over $100 \mathrm{M}$ website views per year

At $\mathrm{BMC}$, research is always in progress.

Learn more biomedcentral.com/submissions 